conductors for use in rectifier cells is selenium. Such cells must not be confused with selenium cells in the photo-conductive class.

\section{Myths of Sun Snaring}

IN a recent paper " Oceanic, American Indian, and African Myths of Snaring the Sun", by Katharine Luomola, Bernice P. Bishop Museum, Bull. 168; 1940) the author has made an exhaustive study of myths and magical practices for sun snaring which she has collated and analysed. In each section the stories and processes are given in full and then compared with each other and with those of the other sections, and by this method possible centres of diffusion have been determined. There are striking similarities in some of the myths, for example, in the use of a woman's hair as a snare, which tale, with variations, seems to have diffused in Polynesia from the Society Islands, and in North America from the Lake Superior Ojibwa and the Menominee.

Other myths show less resemblance and could easily have arisen independently, and on the whole the author's conclusion is that the evidence is not sufficient to show a common origin for these two areas. Similarly with the African myths and magical processes; although there are parallels between the Nandi and the Melanesians in knotting grass to retard the sun, this alone can scarcely be sufficient evidence of contact. As regards cat's-cradles, the author is mistaken in her statement that these are forbidden by the Iglulik during the winter; according to Jenness, this is the season at which they are allowed. There are two distribution maps, numerous authorities are quoted and the paper forms a useful addition to the study of sun myths.

\section{Canadian Aerial Forestry for Burma}

IN the Indian Forest Records (Silviculture (New Series), 4, No. 1 ; Govt. of India Press, New Delhi, 1940), Mr. J. D. Braithwaite of the Burma Forest Service discusses the great advance which has been made in discovering comparatively cheap methods of applying aerial survey to solve forestry problems, and considers that these methods should be applicable to Burma. Burma started before India in making use if the aeroplane in connexion with the forests, for during 1924-25 the Delta and the Heinze Basin were both surveyed from the air with good results. Mr. Braithwaite relates that immense strides have been made in Canada in air work in the last ten to twelve years-strides which were to a great extent unknown even to the United States alongside. Their chief importance is their practical nature and cheapness as compared with methods in force in England, or, to quote an example given by the author, Germany, where he remarks "the scientists have got hold of both the photographic and mapping operations to such an extent that a very expensive and highly trained staff is needed to work the very delicate and costly machinery that has been pains. takingly developed".
Obviously this would be as useless as impossible for the great areas of the Empire forests. It is in this simplification and cheapening of methods to. which Canadian investigators have directed themselves, and Mr: Braithwaite during a visit to Canada for the purpose was able to study the work with thoroughness, as his monograph well displays. Some of the forestry problems of chief importance in which aerial survey can give the greatest assistance are (1) the problem of mapping small plantations; (2) the thinning of young plantations and an examination of the degree of stocking; (3) stockmapping, and the distinguishing of individual species in a mixed forest, from the air.

\section{Horticulture of the Amaryllidaceae}

THE title of the periodical Herbertia, though somewhat concealing to the uninitiated, covers a concentrated scientific approach to the horticulture of the Amaryllidaceæ. It appears as the yearbook of the American Amaryllis Society (from the Editor, Dr. H. P. Traub, Orlando, Florida, U.S.A.). Vol. 7 for 1940 announces the deseription of two new species, Amaryllis aglaice and Zephyranthes Fosteri; it discusses the phylogenetic position of several groups within the natural order, and acts as a genetic record for the origins of many hybrid introductions. The first part of a large-scale review of the breeding and testing of day-lilies (Hemerocallis) further indicates. the sources of various characters which have been combined to form clones of proved horticultural excellence.

A paper by Dr. A. B. Stout correlates the vigour of shoot growth with the origin of a clone, and W. M. James outlines briefly the methods of growing Alstroemerias from seed. Germination is optimum when the seed has been subjected to a temperature of $77^{\circ} \mathrm{F}$. for two months, followed by one month at $50^{\circ} \mathrm{F}$. The same author has also a short paper on the best conditions for harvesting and storage of amaryllid bulbs. A method of preserving herbarium specimens in their natural colours by drying in sand is described by Dr. H. P. Traub. Herbertia ministers to the practical cultivation of its particular group of plants ; it also maintains a welcome personal character, for the pioneers of Amaryllid culture are described in biography. The volume is withal an excellent example of what yearbooks should be.

\section{Celluloid for Cycle Accessories}

ONE of the most interesting features in the development of the British bicycle industry during the past sixty years has been the growth of a group of specialist manufacturers whose products have had a great deal to do with the success of the modern British lightweight bicycle in the markets of the world. The Export Trader of August says that by careful experiment, continuous research and insistence on high quality they have produced components, parts and accessories for bicycles in steel, rubber, celluloid and other materials which, because of their lightness combined with their strength and durability, have enabled British cycle manufacturers 
to turn out machines better than those of any other country.

Among this group of specialist manufacturers is the firm of Bluemel Bros., Ltd., Woolston, near Coventry. At an early stage in the firm's history the brothers Bluemel realized the advantages of the application of celluloid with its inherent lightness and freedom from dust to bicycle design, and now a large number of the accessories which the firm manufactures are made of this material. The celluloid type tyre inflator was a great success from the start. It was able to withstand the rough and tumble of every-day usage without becoming dented and thus put out of service. Its smooth and easy action is also another commendable feature. Later the Company started to produce celluloid chain covers for cycles. Celluloid mudguards have also been very successful. Quickly detachable fittings of light construction enable the rider to attach or remove them without interfering with the wheels. Celluloid cycle handles are coated with strong adhesive and only require moistening before placing on the handlebars. The 'Cushion Grip' rubber handle is very comfortable to use, although, unlike sponge rubber, it does not absorb moisture.

\section{Recent Earthquakes}

TwEnTy well-established earthquakes were registered at the Swiss observatories in March 1941, and nineteen in April 1941, according to the bulletins just received. Some of these were distant earthquakes mentioned previously in NaTuRE, but some were local. On March 12 an earthquake was felt with intensity 4 on the Rossi-Forel scale at Lokalstoss in Andermatt. On March 28 an earthquake with intensity 3-4 was felt in Canton Graubunden, its epicentre probably being south-east of the Ortlergruppe. On March 29 an earthquake with its epicentre near Oberwallis was felt in Visp with intensity 4. The only local shock in April was apparently on April 6 and had an epicentre near Val d'Anniviers and was felt in Vissoie with intensity 5.

The Jesuit Seismological Association of St. Louis has recently determined the epicentres of two strong earthquakes. The first shock was on January 5, 1941 , with tentative calculated epicentre $2 \cdot 0^{\circ} \mathrm{S}$., $123 \cdot 7^{\circ} \mathrm{E}$. and $T_{0} 18 \mathrm{~h} .46 \mathrm{~m} .44 \mathrm{~s}$. G.M.T. The depth of focus was considered somewhat deeper than normal, and this is not surprising since earthquakes from this region are often from a deeper than normal focus. The epicentre is near the centre of the island of Celebes in the Dutch East Indies. The second was on February 9, 1941, and was felt at Eureka, California. The tentative epicentre was calculated to be at $41 \cdot 1^{\circ} \mathrm{N}$., $125 \cdot 5^{\circ} \mathrm{W}$. with $T_{0} 9 \mathrm{~h} .44 \mathrm{~m}$. 5s. G.M.T. and depth of focus probably near normal. It probably had the same epicentre as the earthquake of January 31, 1922, which has been described by J. B. Macelwane, S.J. (Bull. Seis. Soc. Amer., 13, 13 ; 1923). For both earthquakes complete readings of seismograms from several American observatories are given.

\section{Theodor Kocher (I84I-I917)}

Prof. THEOdor Kocher, one of the most famous of recent scientific surgeons, was born on August 25, 1841, at Bern, where he received his medical education and qualified in 1865. After a postgraduate tour abroad he returned to Bern, where he served as Lueck's assistant and succeeded him as professor of surgery in 1872. Though there is scarcely a branch of surgery to which he did not make some valuable contribution, he is best known for his work on the thyroid gland, for which he was awarded the Nobel Prize in 1911. In 1878 he was the first to excise this organ for goitre, and afterwards performed this operation on more than two thousand cases. At an early stage of his career he recognized the value of antiseptic methods, which he was the first to introduce into Switzerland. $\mathrm{He}$ was one of the founders of abdominal surgery, especially as regards operations on the stomach, gall-bladder and rectum. His name has been given to a method of reducing dislocation of the humerus, an operation for inguinal herniaand numerous instruments. Throughout his life he paid constant attention to anatomy and operations on the cadaver.

Kocher's principal publications were the "Operationslehre", which was translated into English, French, Italian, Spanish and Russian, lectures on surgical infections and forms of fracture. He was also the author of works on diseases of the testis and on gunshot wounds, as well as of numerous contributions to periodical literature. He received many honours in his own country, including the presidency of the Bern Medical Society, the Swiss Medical Committee and the Swiss Society of Pathology, as well as foreign distinctions such as the honorary fellowship of the Royal College of Surgeons of England and the presidency of the German Society of Surgery and of the International Congress of Surgery held at Brussels i 1 1905. In 1912 in honour of the for tieth anniversary of his appointment as professor he was the recipient of a Festschrift which formed the 116 th volume of the Deutsche Zeitschrift für Chirurgie. He died after an abdominal operation on July 27, 1917.

\section{Announcements}

THE following appointments and promotions in the Colonial Service have recently been made: $R$. W. Ford, veterinary officer, Gold Coast ; T. T. Threlkeld, veterinary officer, Jamaica; B. D. Evans (assistant director), director, Royal Observatory, Hong Kong.

FIve hundred bottles of blood serum prepared at the University of Toronto in a laboratory furnished by the Canadian Government are being sent to the National Institute for Medical Research, London, for the treatment of air-raid casualties.

BY an Order of the Committee of Privy Council, made after consultation with the Medical Research Council and with the president of the Royal Society, Mr. E. Rock Carling (senior surgeon to the Westminster Hospital) and Prof. S. P. Bedson (professor of bacteriology in the University of London) are appointed members of the Medical Research Council, in succession to Prof. G. E. Gask and Prof. W. W. C. Topley, who retire on September 30. 